\title{
Insecticide Resistance in Plutella xylostella (L.) (Lepidoptera: Yponomeutidae) in the Federal District, Brazil
}

\author{
Marina Castelo Branco ${ }^{1}$ and Alexander G. Gatehouse ${ }^{2}$ \\ ${ }^{1}$ Centro Nacional de Pesquisa de Hortaliças, EMBRAPA, Caixa postal 218, \\ 70.359-970, Brasília, DF. \\ ${ }^{2}$ University of WaIes. School of Biological Sciences. Brambell Building. \\ Bangor. Gwynedd. LL57 2UW, United Kingdom.
}

An. Soc. Entomol. Brasil 26(1): 75-79 (1997)

\section{Resistência de Plutella xylostella (L.) (Lepidoptera: Yponomeutidae) a Inseticidas no Distrito Federal}

\begin{abstract}
RESUMO - Os níveis de resistência aos inseticidas cartap, deltametrina e metamidofós foram avaliados em três populações de Plutella xylostella (L.) provenientes do Distrito Federal em laboratório. Os níveis de resistência a deltametrina variaram de 4 a 47 vezes quando comparados a uma população susceptível de laboratório. Já os níveis de resistência à metamidofós se situaram entre 2 e 9 vezes. Não foi encontrada resistência à cartap.
\end{abstract}

PALAVRAS-CHAVE: Insecta, traça das crucíferas, resistência a inseticidas.

ABSTRACT - The levels of resistance to the insecticides cartap, deltamethrin and metamidophos were evaluated for three populations of the Diamondback Moth Plutella xylostella (L.) from the Federal District, Brazil in laboratory bioassays. The larvae of DBM showed levels of resistance to deltamethrin between 4 and 47 fold relative to a susceptible laboratory strain. The level of resistance to metamidophos was 2-9 fold greater than that of the susceptible strain. No resistance to cartap was detected.

KEY WORDS: Insecta, Diamondback moth, insecticide resistance.

The Diamondback moth (DBM) Plutella xylostella (L. ) is a cosmopolitan insect that occurs exclusively on Cruciferae and other plants that contain mustard oils (Thorsteinson 1953, Fraenkel 1959). In several countries like Japan (Hama 1990), Taiwan(Cheng 1988), Malaysia (Chua \& Ooi 1986), USA (Shelton \& Wyman 1992) and Brazil (França et al. 1985) DBM is an importantpestofcabbage.

In order to reduce the damage by insects growers use several appiications of different insecticides (McLaughlin et al. 1994). The in- tense use of insecticides has led to the appearance of populations resistant to pyrethroids (Liu et al. 1982, Rama 1987),organophosphorous (OPs) (Miyata et al. 1982), insect growth regulators (Lin et al.1989), and Bacilius thuringiensis (Berliner) (Tabashnik et al. 1987, Hama et al. 1992).

In the Federal District, Brazil, metamidophos and deltamethrin are the insecticides most commonly used to control DBM. Weekly sprays are used at the begining of the dry season (March-June) when the pest popula- 
tion density is low. However, from the middle to the end of the dry season (July-November), when the population density increases insecticides are applied two to three times week. Resistance to insecticides in DBM in Brazil is not documented. Due to constant control failure of insecticides in the field, S. Barbosa \& F. H. França (unpublished) suggested that DBM could be resistant to OPs and carbamate, and França et al. (1985) and Castelo Branco \& Melo (1992) suggested resistance to pyrethroids.

The objective of this study was to determine the level of resistance to cartap, deltamethrin and metamidophos in larvae of DBM populations collected in the Federal District, Brazil.

\section{Material and Methods}

Populations. The susceptible population named LAB was obtained from Imperial College of Science, Technology and Medicine, University of London. Populations named BZD, PADF and VB were collected, respectively, at Núcleo Rural de Braziândia, Núcleo Rural PADF, and Núcleo Rural da Vargem Bonita in the Federal District, Brazil. These three populations descended from insects collected in the field between 31 July-1st September 1994. The population BZD came from an area were pyrethroids and OPs were used. In the area where the populations VB carne from only pyrethroids were used. The population PADF came from an organic grower area where insecticides were not being used for more than five years.

Rearing Procedures. Adults of each population were released in cages $(70 \times 70 \times 70 \mathrm{~cm})$. During the first 3-d after emergence, four leaves of Chinese cabbage Brassica oleracea c v. Tip Top were placed in $50 \mathrm{ml}$ vials filled with water and then put in the cage. After the 4th day, only two leaves were put in the cage and they were replaced every one or two days, depending on the frequency of oviposition by the females.

After being collected from the cages, the leaves were put in a plastic box $(25 \times 12 \times 8 \mathrm{~cm})$ where the eggs hatched. The boxes were kept in a controlled-environment room at $20^{\circ} \mathrm{C}, 50$ $60 \% \mathrm{RH}$ and a photoperiod of 13L: $11 \mathrm{D}$. Every day a fresh leaf of Chinese cabbage was supplied to the larvae in the boxes. No more than 100 larvae were reared per box.

Bioassay. The four populations (1st generation of BZD and 2nd of PADF and VB) were exposed to the insecticides deltamethrin and rnetamidophos. Populations LAB and BZD (2nd generation) were exposed to the insecticide cartap .

As a rule, five doses with 40 larvae (10 insects/replication) were used for each insecticide. A surfactant (ethylene oxide condensate) at a rate of $20 \mathrm{ml} / 100$ liter of water was added to each solution and a control (water + surfactant) was used for each replication. Leaf tissue disks of $4 \mathrm{~cm}$ diameter were cut from Chinese cabbage leaves and submerged in each solution for five seconds and then allowed to dry in the environment for 1-h. After this period, the individual disks were placed in a $4.5 \mathrm{~cm}$ diameter Petri dish with a moistened filter paper and the larvae were transferred to the leaf disks. Treatments were kept at $20^{\circ} \mathrm{C}$ in a photopheriod of 13L:11 D. Mortality was assessed at $24 \mathrm{~h}$ for metamidophos and at $48 \mathrm{~h}$ for deltamethrin and cartap. Larvae were considered dead if they did not move after $10 \mathrm{~s}$. of being probed with a camel hairbrush. If mortality in the controls were higher than $10 \%$, the replication was discarded. Alli the solutions were calculated assuming an application rate of 400 liters of water/ha.

Analysis. Data for each insecticide / population was analysed by probit analysis (Finney 1971) and Abbot's formula (Abbott 1925) was used to correct for control mortality. The ratio of the LC50 of populations from the field to the LC50 of the susceptible laboratory population was calculated for each insecticide and population in order to determine the resistance factor (RF). The levels of resistance of the populations were considered significantly 
different if the $95 \%$ confidence limits of the LC50 values did not overlap.

\section{Results and Discussion}

There was a considerable difference among populations in the level of resistance to deltamethrin and metamidophos. The population BZD was the most resistant population. When compared with the LAB population, BZD was 47 fold more resistant to deltamethrin and nine fold more resistant to metamidophos (Table 1). The population VB was also resistant to deltamethrin (27 fold) and showed low levels of resistance to metamidophos (two fold). The population from the organic growers' area (PADF) had low levels of resistance to deltamethrin (four fold) and metamidophos (three fold) (Table 1). The three field populations were signifícantly different from each other in relation to the level of resistance to deltamethrin [the 95\% confidential limits of the LC50s did not overlap (Table 1)] but there was no difference between populations PADF and VB in relation to the insecticide metamidophos (the 95\% confidence limits of the LC50 overlapped).

The levels of resistance to deltamethrin and metamidophos observed in larvae of the field populations was related to the know pattern of usage of the insecticides. The population BZD came from an area where the two insecticides are commonly used and showed the highest level of resistance to both insecticides (Table 1). On the other hand, the population VB came from an area were only pyrethroids were used to control DBM. This population showed an intermediate level of resistance to pyrethroids and a low level of resistance to OPs.

Although it was observed that the populations of DBM from Brazil were resistant to

Table 1. Evaluation of susceptibility to metamidophos, deltamethrin and cartap in Plutella xylostella.

\begin{tabular}{|c|c|c|c|c|}
\hline Population & $\mathrm{n}$ & $\begin{array}{c}\text { LC50 (CL 95\%) } \\
\text { (g.a.i/ha) }\end{array}$ & Slope \pm SD & $\mathrm{RF}^{\prime}$ \\
\hline
\end{tabular}

\section{Metamidophos}

$\begin{array}{ll}\mathrm{LAB}^{2} & 21 \\ \mathrm{PADF}^{3} & 22 \\ \mathrm{VB}^{3} & 24 \\ \mathrm{BZD}^{3} & 256\end{array}$

\section{Cartap}

\section{$\mathrm{LAB}^{2}$}

$\mathrm{BZD}^{3}$

Deltamethrin

257

$92(70-118)$
$289(135-233)$
$208(154-252)$
$843(710-1000)$

$1.87 \pm 0.26$

$2.74 \pm 0.35$

$3.61 \pm 0.63$

$2.63 \pm 0.27$
$1.25 \pm 0.13$

$1.74 \pm 0.26$

$2.88 \pm 0.52$

$2.45 \pm 0.27$

1
3
2
9

23(15-34) $17(9-16)$
$2.74 \pm 0.48$ $1.48 \pm 0.17$

\section{1}

4

27

47

${ }^{1}$ Resistance Factor $=$ LC50 population tested/ LC50 LAB population.

${ }^{2} \mathrm{LAB}$ - Laboratory susceptible population.

Populations collected in grower's areas in the Federal District. 
deltamethrin and metamidophos, the levels of resistance were low when compared with the results obtained in Taiwan with deltamethrin (1850 fold, Sun et al. 1992) and in Honduras with metamidophos (224 fold, Ovalle \& Cave 1989). In the Federal District, there is a period during the rainy season (November till March) when the population of DBM is low (Castelo Branco \& Melo 1992). During this period little or no insecticide is applied. Some authors suggested that in the absence of applications of insecticides, a decrease in the level of resistance could occur (Hama 1987, Armes et al. 1992, Murai et al. 1992). But Roush \& Plapp (1982) suggested that this reversion could have no effect in reducing the level of resistance. As the effect of interrupting insecticide application on levels of resistance of DBM have never been investigated in the field in Brazil, the occurrence of any significant reversion and its impact on the level of resistance remains to be evaluated.

No differences in susceptibility to cartap were found between the LAB and BZD populations. In fact, the population BZD was marginally less tolerant to cartap when compared with the population LAB (Table 1). As this insecticide has never been used in this area, it would be expected that no level of resistance would be found.

\section{Acknowledgements}

To EMBRAPA who provided the scholarship for the realization of this work. To Dr. Félix H. França $(\mathrm{CNPH})$ for reading this manuscript and for the collection of DBM. To Dr. Geni L. Villas Boas and Hozanan P. Chaves $(\mathrm{CNPH})$ and Dr. Débora M. R. Cruz and Dr. Roberto C. Carneiro (EMATER/DF) who helped in the collection of the DBM. To Dr. D.J. Wright from Imperial College, who provided the susceptible population of DBM. To the growers of the Federal District who permitted the work in their areas. To Nigel Brown from
University of WaIes, who provided the Chinese cabbage.

\section{References Cited}

Abbott,W.S. 1925. A method of computing the effectiveness of an insecticide. J. Econ. Entomol. 18:265-267.

Armes,N. J., D. R. Jadhav, G. S. Bond \&A.B. S. King. 1992. Insecticide resistance in Helicoverpa armigera in South India. Pestic. Sci.. 34:355-364.

Castelo Branco, M. \& P. E. de Melo 1992. Avaliação de inseticidas e bioinseticidas para o controle da traça das crucíferas no Distrito Federal. Hort. Bras. 10:116-117.

Cheng,E.Y. 1988. Problems of control of insecticide-resistant Plutella xylostella. Pestic. Sci. 23:177-188.

Chua, T. H. \& A. C. Ooi. 1986. Evaluation of three parasites in the biological control of Diamondback Moth in the Cameron Highliands. p. 173-184. In: N.S.Talekar \& T. D. Griggs (eds.). Diamondback Moth management. Proc. First Int. Workshop, Taiwan, Asian Vegetable Research and Development Center.

Finney, D. J. 1971. Probit analysis. Cambridge, University Press.

Fraenkel, G. S. 1959. The raison d'étre of secondary plant substances. Science 129: 1466-1470.

França, F. H., C. M. T. Cordeiro, L. de B. Giordano, \& A. M. Resende. 1985. Controle da traça das crucíferas em repolho, 1984. Hort. Bras. 3:47-53.

Hama, H. 1987. Development of pyrethroid resistance in the Diamondback Moth. Appl. Entomol. Zool. 22:166-175. 
Hama,H. 1990. Insecticide resistance of Diamondback Moth, Plutella xylostella. | JARQ 24:22-30.

Hama,H., K. Suzuki \& H. Tanaka. 1992. Inheritance and stability of resistance to Bacilius thuringiensis formulations of the Diamondback Moth, Plutella xylostella (Linnaeus) (Lepidoptera: Yponomeutidae). Appl. Entomol. Zool. 27: 355-362.

Lin,J.G., C.H. Hung \& C.N. Siin. 1989. Teflubenzuron resistance and microsomal monooxygenases in larvae of the Diamondback Moth. Pestic. Biochem. Physiol. 35:20-25.

Liu, M. Y.; Y. J. Tzeng \& C. N. Sun. 1982. Diamondback Moth resistance to several synthetic pyrethroids. J. Econ. Entomol. 74:393-396.

McLaughlin,J. R.; E. R. Mitchell \& P. Kirsch. 1994. Mating disruption of Diamondback Moth (Lepidoptera: Pluteilidae) in cabbage: reduction of mating and supression of larval populations. J. Econ. Entomol. 87:1196-1204.

Miyata,T, H. Kawai \& T. Saito. 1982. Insecticide resistance in the Diamondback Moth Puitella xylostella L. (Lepidoptera: Yponomeutidae). Appl. Entomol. Zool. 17:539-542.

Murai, T., M. Miyazaki \& M. Ozuka. 1992. Changes in insecticide susceptibility of the Diamondback Moth in Shimane, Japan.JARQ26:152-156.
Ovalle,G.O. \& R.D. Cave. 1989. Determinación de resistência de Plutella xylostella L. (Lepidoptera: Plutellidae) a insecticidas comunes en Honduras. Ceiba 30:119-128.

Roush,R.T. \& F.W. Plapp Jr. 1982. Effects of insecticide resistance on biotic potential of the house fly (Diptera: Muscidae). J. Econ. Entomol. 75:708-713.

Shelton, A. M. \& J. A. Wyman. 1992. Insecticide resistance of Diamondback Moth in North America, p.447-454. In: N.S. Talekar. (ed.). Diamondback Moth and other crucifer pests. Proc. Second Int. Workshop, Taiwan, Asian Vegetable Research and Development Center.

Sun,C.N.,T.K.Wu., J.S. Chen \& W.T. Lee. 1986. Insecticide resistance in Diamondback Moth. p. 359-371. In: N.S.Talekar \& T.D. Griggs (eds.). Diamondback Moth management. Proc. First Int. Workshop, Taiwan, Asian Vegetable Research and Development Center.

Tabashnik, B. E., N. L. Cushing \& M. W. Johnson. 1987. Diamondback moth (Lepidoptera: Plutellidae) resistance to insecticides in Hawaii: intra-island variation and cross-resistance. J. Econ. Entomol. 80: 1091-1099.

Thorsteison, A. J. 1953. The chemistatic responses that determine host specifícity in an oligophagous insect (Plutella maculipennis) (Curt) (Lepidoptera). Can. J. Zool. 31:52-72.

Received 04/XII/95. Accepted 27/I/97. 